\title{
Measurement of GLP-1 in Impaired Glucose Tolerance Subjects in Comparison to Type 2 Diabetes Patients and Healthy Subjects
}

\author{
Ahmed Abdullah Ebeid ${ }^{1}$, Mohammad Hosam El-deen Zaghloul ${ }^{2}$, Mahmoud Abdulhakam Darwish ${ }^{1} \&$ Ossama A. \\ Mansour $^{1}$ \\ ${ }^{1}$ Biochemistry Department, Al Azhar University College of Pharmacy, Cairo, Egypt \\ ${ }^{2}$ Clinical Pathology Department, Faculty of Medicine, Mansoura University, Egypt \\ Correspondence: Mahmoud Abdulhakam Darwish, Faculty of Pharmacy, Al Azhar University, Cairo, Egypt. Tel: \\ 002-0100-911-4052. E-mail: mahmoud_abdulhakam@yahoo.com
}

Received: July 8, 2013 Accepted: August 13, 2013 Online Published: September 9, 2013

doi:10.5539/ijb.v5n4p29 URL: http://dx.doi.org/10.5539/ijb.v5n4p29

\begin{abstract}
Background: Incretin therapy of type 2 diabetes patients is based on the fact that Incretin Effect is diminished in those patients. The objective is to measure glucagon-like peptide-1 (GLP-1) levels in impaired oral glucose tolerance (IGT) subjects and compare them to those of type 2 diabetes patients and healthy subjects. If the incretin hormone (GLP-1) is established to be diminished in IGT subjects, future study may assess effectiveness of incretin therapy to prevent or delay diabetes in IGT subjects.
\end{abstract}

Patients and methods: GLP-1 was measured by ELISA test at 0,30 and 120 minutes in accordance with OGTT in three groups: type 2 diabetes groups including 24 patient, impaired glucose tolerance group including 24 subject and healthy control group including 24 subject as control. Patients were classified according to the WHO criteria for diabetes diagnosis.

Results: Fasting GLP-1 levels were none significantly different between the studied groups. One the other hand, GLP-1 response at $30^{\prime}$ was significantly diminished in diabetics when compared with IGT and controls. GLP-1 levels at $120^{\prime}$ were significantly reduced in type 2 diabetes patients when compared with IGT and controls and significantly diminished in IGT when compared with controls.

Conclusions: The study indicates that the GLP-1 levels are diminished in impaired glucose tolerance subjects when it's compared to normal subjects.

Keywords: impaired glucose tolerance, diabetes, GLP-1

\section{Introduction}

\subsection{Type 2 Diabetes Disease Burden}

It was expected that the number of People with diabetes would increase from 171 million in 200 to reach 366 million in 2030 but the prevalence globally already reached 371 by 2012 as indicated by the International Diabetes Federation (IDF), and the calculated projections globally indicate that the prevalence of diabetes will reach 530 million people in 2030 (IDF, 2012). In 2012, Egypt came in the top ten countries in the prevalence of diabetes occupying the seventh place with $16.9 \%$ of population between $20-79(48,305,000)$ which is as many as 7,548,750 type 2 diabetes patient, and an estimated undiagnosed patients reaching 4,207,295, where between $6.8 \%$ and $7.5 \%$ are impaired glucose tolerance subjects accounting for about 3,304,696 this contributed to as many as 65003 cases with diabetes related deaths. Surprisingly the diabetes related expenditure per person with diabetes were estimated only 136 USD per year (IDF, 2012).

Many treatment regimens were applied for treatment and only the newly introduced incretin therapy can claim the ability to change the nature of diabetes form a progressive disease to static disease through their assumed ability to preserve b-cell function (Farilla et al., 2003). Incretins are gastrointestinal hormones secreted in response to nutrient ingestion. They work on the beta cells in the pancreas stimulating glucose-dependent insulin secretion. The incretin hormones responsible predominantly for this enteral-insulin relationship are glucagon-like peptide-1 (GLP-1) and glucose-dependent insulinotropic peptide (GIP). Also GLP-1 secretion is regulated by neural and endocrine factors (Drucker \& Nauck, 2006). 
In addition to their ability to stimulate glucose secretion in a glucose dependant manner, GLP-1 is able to exert other metabolic properties that control glucose homeostasis, that includes suppression of glucagon from the alpha cells in pancreas, improvement of glucose utilization and disposal and slowing of gastric emptying (D' Alessio \& Vahl, 2004; Zander, Madsbad, Madsen, \& Holst, 2002). By slowing the gastric absorption of nutrients and promoting a feeling of satiety GLP-1 can lead to weight loss in overweight individuals (Gautier, Fetita, Sobngwi, \& Salaun-Martin, 2005). Studies in both animals and humans revealed that GLP-1 may also have protective effects on the cardiovascular system (Drucker \& Nauck, 2006). Furthermore, in animal studies, both GLP-1 and GIP were able to increase beta-cell mass, by promoting islet cell proliferation and inhibition of apoptosis (Brubaker \& Drucker, 2004). Based on the previous data, enhancing of incretin action has emerged as apotential therapeutic goal in the development of new therapies for the management of type 2 diabetes.

In past studies, (Toft-Nielsen et al., 2001) and (Vilsboll, Krarup, Deacon, Madsbad, \& Holst, 2001), Toft-Nielsen et al. (2001) reported $\sim 20$ and $\sim 30 \%$ lower postprandial GLP-1 levels in IGT subjects and patients with type 2 diabetes compared with normal oral glucose - tolerant subjects, respectively. In line with these data, Vilsboll et al. (2001) found not only total but also intact GLP-1 levels to be reduced in patients with type 2 diabetes.

However, in subsequent studies, other investigators failed to detect such differences in GLP-1 levels in another group of patients with type 2 diabetes (Ryskjaer et al., 2006).

\subsection{Aim of Work}

The aim is to compare the GLP-1 levels between IGT subjects, type 2 diabetes patients and healthy subjects. If the GLP-1 levels were found to be diminished in IGT subjects that will help us consider incretin based therapy effectiveness in preventing or delaying diabetes.

\section{Patients and Methods}

This study was conducted on 72 adults, during the period from June 2012 till January 2013, who were classified into three groups based on their performance in a standard Oral Glucose Tolerance Test (OGTT) (WHO, 2006). GLP-1 was measured by ELISA at 0,30 and 120 Minutes in accordance with the OGTT in the tree groups. Patients were recruited in diabetes outpatient clinic at Mansoura University, and laboratory analysis was performed in biochemistry department in Al Azhar College of Pharmacy. The study population was selected from type 2 diabetes patients' families and friends who usually escort them to the hospital. In the hospital, those relatives and friend were offered to participate in the study.

Patient demographic for each study member were recorded including age (in years) and Body Mass Index (BMI) as $\left(\mathrm{kg} / \mathrm{m}^{2}\right)$.

\subsection{Type 2 Diabetes Group}

This group includes 24 patients. A screening process was performed to select group subjects. Diabetes group were chosen to be newly diagnosed and drug naïve neither taking oral therapy nor insulin, to limit the effect of type 2 diabetes disease length on the hormone level if any, bearing in mind that a patient with 10 to 15 years of type 2 diabetes may have different hormone profile than a patient with shorter duration of disease. Patient were included in this group if fasting plasma glucose $\geqslant 7.0 \mathrm{mmol} / \mathrm{l}(126 \mathrm{mg} / \mathrm{dl})$ and $2-\mathrm{h}$ plasma glucose $\geqslant$ $11.1 \mathrm{mmol} / \mathrm{l}(200 \mathrm{mg} / \mathrm{dl})$.

\subsection{Impaired Glucose Tolerance Group}

This group included 24 patients. While the impaired glucose tolerance group was expected to take long time to complete the patient recruitment but it did not, taking only 10 days, giving an idea about how much prevalent is the disease in Egypt. Patients were included in this group if their fasting plasma glucose level $\geqslant 6.1 \mathrm{mmol} / 1$ $(110 \mathrm{mg} / \mathrm{dl})$ and $<6.9 \mathrm{mmol} / \mathrm{l}(125 \mathrm{mg} / \mathrm{dl})$ and $2-\mathrm{h}$ plasma glucose $\geqslant 7.8$ and $<11.1 \mathrm{mmol} / \mathrm{l}(140 \mathrm{mg} / \mathrm{dl}$ and $200 \mathrm{mg} / \mathrm{dl}$ ).

\subsection{Healthy Control Group}

This group included 24 subjects with normal fasting plasma glucose as $<5.6 \mathrm{mmol} / \mathrm{l}$, and a normal $2-\mathrm{h}$ plasma glucose as $<7.8 \mathrm{mmol} / 1(140 \mathrm{mg} / \mathrm{dl})$. An indicator of the stealthy nature of the disease, another aspect was noticed while recruiting patients. In the diabetes group of the 24 subject, 4 patients were diagnosed with diabetes who were otherwise completely healthy and self-reported no complain of type 2 diabetes symptoms, and were primarily expected to be in the control group, while of 24 subjects in the impaired glucose tolerance (prediabetes) group, 14 subjects self-reported no complain of any type 2 diabetes symptoms and completely healthy and also were expected to be in the control group. 


\subsection{Blood Samples Withdrawal}

We collected the blood samples into centrifuge-safe lavender vacutainer tubes, which contain EDTA for blood anticoagulation and Aprotinin ( $0.6 \mathrm{TIU} / \mathrm{ml}$ of blood) to inhibit the activity of proteinases and can collect $7 \mathrm{ml}$ blood/tube. Then we gently rock the centrifuge-safe lavender vacutainer tubes several times immediately after collection. After that we centrifuge the blood at $1,600-\mathrm{x}$ g for 15 minutes at $4{ }^{\circ} \mathrm{C}$ after that we collected the plasma. Plasma was then kept at $-70{ }^{\circ} \mathrm{C}$.

Blood was also collected for Blood Glucose (BG), insulin and HbA1c measurement. BG measured at 0,30 and 120 minutes in accordance with the OGTT in the tree groups. Insulin was measured at 0 and 120 minutes and $\mathrm{HbA1c}$ at 0 minute.

\subsection{Extraction of GLP-1 Peptide From Plasma}

We first acidified the plasma with an equivalent amount of buffer $\mathrm{A}$. Then we mixed and centrifuged it at 6000 to 17000 -x $\mathrm{g}$ for 20 minutes at $4{ }^{\circ} \mathrm{C}$. After that we equilibrated a SEP-COLUMN that contains $200 \mathrm{mg}$ of $\mathrm{C} 18$ via washing with buffer $\mathrm{B}$ ( $1 \mathrm{ml}$ once) then by buffer A ( $3 \mathrm{ml}, 3$ times).

After this step no pressure was applied to the column. Then we loaded the acidified plasma solution onto the pretreated C18 SEP-COLUMN and slowly washed the column with buffer A ( $3 \mathrm{ml}$ twice) and we discarded the wash. Then we eluted the peptide slowly using buffer B $(3 \mathrm{ml}$ once) and collected the eluant in a polystyrene tube then we evaporated the eluant to dryness in a centrifugal concentrator.

The dried extract was then kept at $-20{ }^{\circ} \mathrm{C}$ and we performed the assay instantly where the assay buffer was used to reconstitute the dried extract.

The absorbance was read in each well at $450 \mathrm{~nm}$. And GLP-1 was measured as ng/ml.

The GLP-1 measuring kit is provided by DRG International Inc., USA. Fax: (908) 233-0758, e-mail: corp@drg-international.com, website: www.drg-international.com and its catalogue details under the name DRG® Glucagon-Like Peptide-1 (Human, Rat, Mouse) ELISA (EIA-4141).

\subsection{Statistical Methods}

Data management and analysis were performed using Data Analysis and Statistical Software for Professionals (STATA) vs. 12. Numerical data were summarized using means and standard deviations or median \& ranges. Comparisons between the 3 groups were performed using one way ANOVA for continuous data and Chi-Square for nominal data. All p-values are two-sided. P-values $<0.05$ were considered significant.

\subsection{Ethical Considerations}

This study was conducted according to Helsinki's declaration and the guidelines for Good Clinical Practice. The local ethics committees approved the protocol, and informed consent was obtained from all patients before study entry.

\section{Results}

\subsection{Patients' Characteristics}

Table 1. Comparison between the studied groups regarding the basic findings, age, BMI, and sex

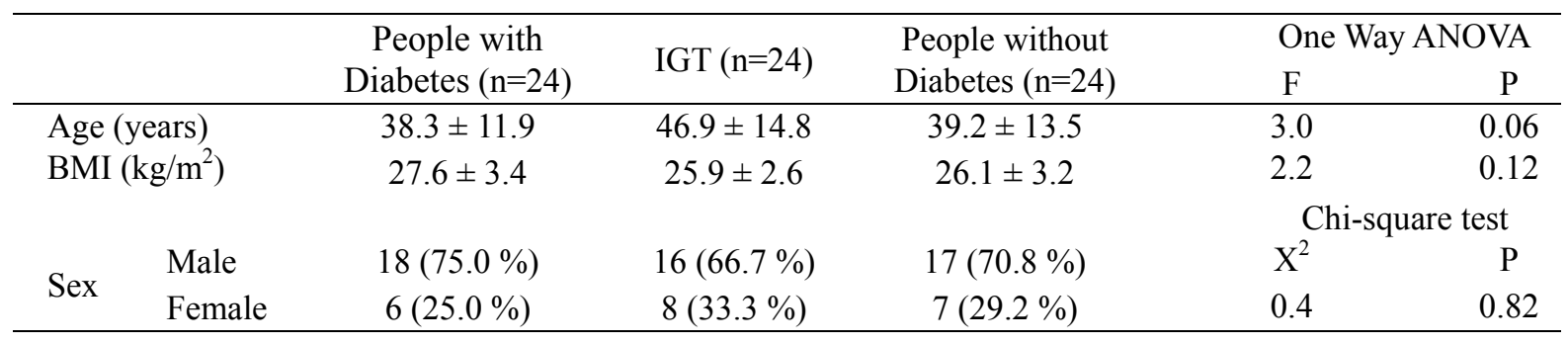

As shown in Table 1, no statistically significant differences were found among the studied groups regarding age, BMI and sex distribution. 


\subsection{Clinical and Pathological Characteristics}

Table 2. Comparison between BG levels in the studied groups, measured as (mg/dl) at 0 (Fasting BG), 30 and 120 minutes

\begin{tabular}{|c|c|c|c|c|c|}
\hline & \multirow{2}{*}{$\begin{array}{c}\text { People with } \\
\text { Diabetes(n=24) }\end{array}$} & \multirow{2}{*}{$\operatorname{IGT}(\mathrm{n}=24)$} & \multirow{2}{*}{$\begin{array}{l}\text { People without Diabetes } \\
\qquad(\mathrm{n}=24)\end{array}$} & \multicolumn{2}{|c|}{ One Way ANOVA } \\
\hline & & & & $\mathrm{F}$ & $\mathrm{P}$ \\
\hline $\begin{array}{l}\text { Fasting } \\
\text { BG }\end{array}$ & $210.0 \pm 53.3$ & $81.0 \pm 2.7$ & $77.0 \pm 2.7$ & 143.9 & $0.0001 *$ \\
\hline BG at $30^{\prime}$ & $261.2 \pm 38.4$ & $142.6 \pm 6.0$ & $120.7 \pm 7.6$ & 260.9 & $0.0001 *$ \\
\hline BG at $120^{\prime}$ & $328.0 \pm 16.9$ & $183.4 \pm 10.9$ & $98.0 \pm 7.9$ & 2071.1 & $0.0001^{*}$ \\
\hline \multicolumn{6}{|c|}{ Post-hoc analysis } \\
\hline \multirow{5}{*}{$\begin{array}{l}\text { Fasting } \\
\text { BG }\end{array}$} & GI & Vs & $\begin{array}{l}\text { GII } \\
\text { IGT }\end{array}$ & \multicolumn{2}{|c|}{$\mathrm{P}$} \\
\hline & People with Diabetes & Vs & IGT & \multicolumn{2}{|c|}{$0.0001 *$} \\
\hline & People with Diabetes & Vs & People without Diabetes & \multicolumn{2}{|c|}{$0.0001 *$} \\
\hline & IGT & Vs & People without Diabetes & \multicolumn{2}{|c|}{$0.0001 *$} \\
\hline & People with Diabetes & Vs & IGT & \multicolumn{2}{|c|}{$0.0001 *$} \\
\hline \multirow[t]{3}{*}{ BG at $30^{\prime}$} & People with Diabetes & Vs & People without Diabetes & \multicolumn{2}{|c|}{$0.0001 *$} \\
\hline & IGT & Vs & People without Diabetes & \multicolumn{2}{|c|}{$0.0001 *$} \\
\hline & People with Diabetes & Vs & IGT & \multicolumn{2}{|c|}{$0.0001 *$} \\
\hline \multirow[t]{2}{*}{ BG at $120^{\prime}$} & People with Diabetes & Vs & \multirow{2}{*}{$\begin{array}{l}\text { People without Diabetes } \\
\text { People without Diabetes }\end{array}$} & \multirow{2}{*}{\multicolumn{2}{|c|}{$\begin{array}{l}0.0001 * \\
0.0001 *\end{array}$}} \\
\hline & IGT & Vs & & & \\
\hline
\end{tabular}

\subsection{Insulin and HbAlc Levels}

Table 3. Comparison between other laboratory findings in the studied groups

\begin{tabular}{|c|c|c|c|c|c|c|c|}
\hline & \multirow{2}{*}{\multicolumn{2}{|c|}{$\begin{array}{c}\text { People with } \\
\text { Diabetes }(n=24)\end{array}$}} & \multirow{2}{*}{ IGT $(n=24)$} & \multirow[t]{2}{*}{ People } & \multirow{2}{*}{$\begin{array}{l}\text { without Diabetes } \\
(\mathrm{n}=24)\end{array}$} & \multicolumn{2}{|c|}{ One Way ANOVA } \\
\hline & & & & & & $\mathrm{F}$ & $\mathrm{P}$ \\
\hline Fasting Insulin & \multicolumn{2}{|c|}{$7.03 \pm 1.97$} & $7.02 \pm 1.38$ & & $7.05 \pm 1.64$ & 0.002 & 0.99 \\
\hline Insulin at $120^{\prime}$ & \multicolumn{2}{|c|}{$61.5 \pm 15.3$} & $56.6 \pm 14.2$ & & $49.3 \pm 15.5$ & 3.95 & $0.024^{*}$ \\
\hline \multirow[t]{3}{*}{$\mathrm{HbA1C}$} & \multicolumn{2}{|c|}{$7.75 \pm 0.76$} & $6.12 \pm 0.19$ & & $5.27 \pm 0.23$ & 167.6 & $0.0001 *$ \\
\hline & \multicolumn{2}{|c|}{ GI } & Vs & & GII & & $\mathrm{P}$ \\
\hline & $\begin{array}{l}\text { People } \\
\text { Diabetes }\end{array}$ & with & Vs & IGT & & & $0.0001^{*}$ \\
\hline \multirow[t]{3}{*}{$\mathrm{HbA1C}$} & $\begin{array}{l}\text { People } \\
\text { Diabetes }\end{array}$ & with & Vs & \multicolumn{2}{|c|}{ People without Diabetes } & & $0.0001 *$ \\
\hline & IGT & & Vs & \multicolumn{2}{|c|}{ People without Diabetes } & & $0.0001 *$ \\
\hline & $\begin{array}{l}\text { People } \\
\text { Diabetes }\end{array}$ & with & Vs & IGT & & & 0.22 \\
\hline \multirow[t]{2}{*}{ Insulin at $120^{\prime}$} & $\begin{array}{l}\text { People } \\
\text { Diabetes }\end{array}$ & with & Vs & \multicolumn{2}{|c|}{ People without Diabetes } & & $0.024 *$ \\
\hline & IGT & & Vs & \multicolumn{2}{|c|}{ People without Diabetes } & & 0.5 \\
\hline
\end{tabular}

Table 2 shows that type 2 diabetes patients had significantly higher fasting BG, BG at $30^{\prime}$ and BG at $120^{\prime}$ than IGT subjects and controls. Also IGT subjects had significantly higher fasting BG, BG at 30' and BG at $120^{\prime}$ than controls. While table 3 shows that type 2 diabetes patients had significantly higher HBA1C than IGT subjects and controls. Also, IGT subjects had significantly higher HBA1C than controls. In addition, it has been shown that diabetics had significantly higher insulin levels than controls at $120^{\prime}$. In spite of the fact that diabetics had higher insulin levels than IGT subjects and IGT subjects had significantly higher insulin levels than controls at 120 ', the difference is statistically short of significance. 


\subsection{GLP-1 Level}

Table 4. Comparison between GLP-1 levels between the studied groups

\begin{tabular}{|c|c|c|c|c|c|}
\hline & \multirow{2}{*}{$\begin{array}{l}\text { People with Diabetes } \\
\qquad(\mathrm{n}=24)\end{array}$} & \multirow{2}{*}{ IGT $(n=24)$} & \multirow{2}{*}{ People without Diabetes } & \multicolumn{2}{|c|}{ One Way ANOVA } \\
\hline & & & & $\mathrm{F}$ & $\mathrm{P}$ \\
\hline Fasting GLP-1 & $0.58 \pm 0.16$ & $0.66 \pm 0.24$ & $0.58 \pm 0.19$ & 1.5 & 0.23 \\
\hline GLP-1 at $30^{\prime}$ & $0.79 \pm 0.08$ & $0.96 \pm 0.28$ & $1.02 \pm 0.15$ & 9.4 & $0.0001 *$ \\
\hline GLP-1 120' & $0.64 \pm 0.07$ & $1.06 \pm 0.2$ & $1.2 \pm 0.18$ & 9.4 & $0.0001 *$ \\
\hline \multirow{5}{*}{$\begin{array}{l}\text { Repeated } \\
\text { measures } \\
\text { ANOVA }\end{array}$} & $\mathrm{F}=17.0$ & $\mathrm{~F}=19.0$ & $\mathrm{~F}=107.0$ & & \\
\hline & $\mathrm{P}=0.0001$ & $\mathrm{P}=0.0001$ & $\mathrm{P}=0.0001$ & & \\
\hline & & Post-hoc an & sis & & \\
\hline & GI & Vs & GII & & $\mathrm{P}$ \\
\hline & People with Diabetes & Vs & IGT & & $0.019^{*}$ \\
\hline \multirow[t]{3}{*}{ GLP-1 at $30^{\prime}$} & People with Diabetes & Vs & People without Diabetes & & $0.0001 *$ \\
\hline & IGT & Vs & People without Diabetes & & 0.68 \\
\hline & People with Diabetes & Vs & IGT & & $0.0001 *$ \\
\hline \multirow[t]{2}{*}{ GLP-1 at $120^{\prime}$} & People with Diabetes & Vs & People without Diabetes & & $0.0001^{*}$ \\
\hline & IGT & Vs & People without Diabetes & & $0.031 *$ \\
\hline
\end{tabular}

The analysis as in Table 4 showed no significant differences between the studied groups regarding fasting GLP-1 levels. On the other hand GLP-1 response at $30^{\prime}$ was significantly diminished in type 2 diabetes when compared with IGT and controls. GLP-1 at $120^{\prime}$ levels were significantly reduced in type 2 diabetes patients when compared with IGT and controls and in IGT when compared with controls. In the same time Repeated measures analysis showed significant differences of GLP-1 levels in all groups throughout the study intervals.

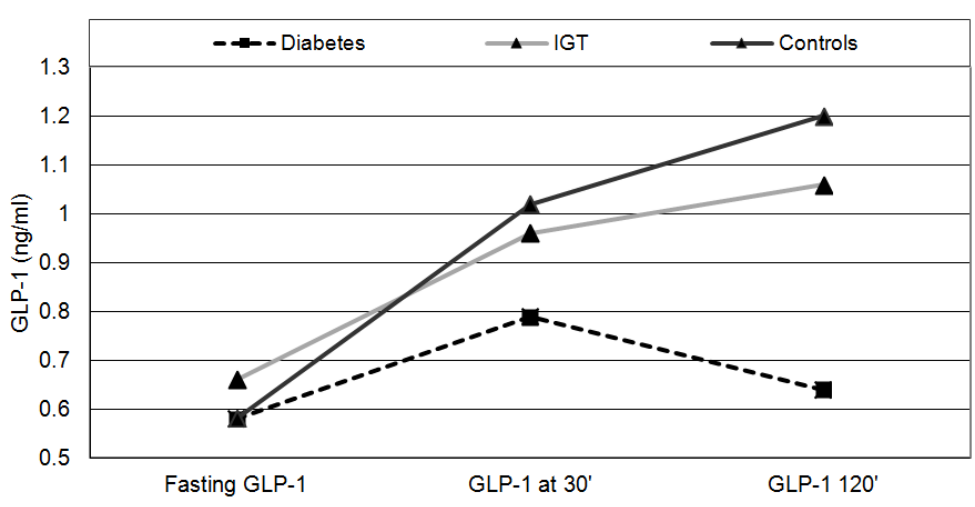

Figure 1. GLP-1 levels in the studied groups

\section{Discussion}

The observation that oral glucose triggers a higher insulin level than parenteral glucose at the same plasma glucose (PG) levels is called the incretin action. The incretin action is attributed to the two main incretin hormones known as glucagon like peptide-1 (GLP-1) and glucose-dependent insulinotropic peptide (GIP) (Holst \& Gromada, 2004).

They are both secreted from the proximal part of the small intestine as response to food ingestion. They cause high insulin secretion a very glucose-dependent manner (Dube \& Brubaker, 2004). The incretin action was proven to be markedly reduced in type 2 diabetes patients. This diminished incretin action come along with a reduced GLP-1 response to a meal with mixed content (Vilsboll et al., 2001), a decreased insulin secreting potency of GLP-1 (Kjems, Holst, Volund, \& Madsbad, 2003) and nearly complete loss of insulin secretion in the late-phase in response to GIP (Vilsboll, Krarup, Madsbad, \& Holst, 2002). 
In addition, it had been proven that the inhibition of glucagon secretion is impaired through oral glucose tolerance tests (OGTTs) in contrast with isoglycemic parenteral infusion of glucose in patients with type 2 diabetes (Knop, Vilsboll, Madsbad, Holst, \& Krarup, 2007). The key observation that the GLP-1 response is blunted and that the $\beta$-cell response to GIP is grossly impaired in diabetes has led to the notion that an impaired incretin effect contributes to the $\beta$-cell incompetence of diabetes (Vilsboll \& Holst, 2004). Clinical data showing that GLP-1 analogs can normalize glycemic state by stimulating insulin secretion in type 2 diabetes patients has strengthened the incretin theory (Zander et al., 2002).

While the aim of the present study is to evaluate levels of GLP-1 in type 2 diabetes patients, IGT patients and non-diabetic healthy subjects, as expected from the study design, type 2 diabetes patients had significantly higher fasting $\mathrm{BG}, \mathrm{BG}$ at $30^{\prime}$ and $\mathrm{BG}$ at $120^{\prime}$ than IGT and controls. Also IGT had significantly higher fasting BG, BG at $30^{\prime}$ and $B G$ at $120^{\prime}$ than controls.

Regarding GLP-1 levels, it had shown no significant differences between the studied groups regarding fasting GLP-1 levels. Meanwhile GLP-1 response at 30' was significantly diminished in type 2 diabetes when compared with IGT and controls. GLP-1 at 120' levels were significantly reduced in type 2 diabetes when it's compared with IGT and controls and in IGT when compared with controls. Repeated measures analysis had shown significant differences of GLP-1 levels in all groups throughout the study intervals.

The present results are in agreement with Toft-Nielsen et al. (2001) and (Vilsbøll et al., 2001). Toft-Nielsen et al. (2001) reported $\sim 20$ and $\sim 30 \%$ lower postprandial GLP-1 levels in IGT subjects and patients with type 2 diabetes compared with normal oral glucose-tolerant subjects, respectively. In line with these data, Vilsboll et al. (2001) found not only total but also intact GLP-1 levels to be reduced in patients with type 2 diabetes. However, in subsequent studies, other investigators failed to detect such differences in GLP-1 levels in another group of patients with type 2 diabetes (Ryskjaer et al., 2006).

The reasons for the dissimilar results in different cohorts of patients are difficult to explain, but it is important to compare the subject characteristics in more detail including diabetes duration and glycemic control. Patients studied by Vilsboll et al. (2001) and Toft-Nielsen et al. (2001) had a longer diabetes duration and exhibited higher A1C levels. It is therefore possible that more defects in GLP-1 secretion develop later during the pathogenesis of type 2 diabetes. In this context, another factor with a potential impact on postprandial GLP-1 levels is the velocity of gastric emptying (Vozzo et al., 2002). Thus, any deceleration of gastric emptying might blunt the subsequent incretin responses (Gentilcore et al., 2006). Another possible factor that might impact on GLP-1 secretion in type 2 diabetes patients is the presence of hyperglucagonemia. In fact, that also appeared in previous studies where high glucagon levels were found to be associated with lower GLP-1 concentrations (Meier, Holst, Schmidt, \& Nauck, 2007).

\section{Conclusion}

The study showed that GLP-1 levels in IGT subjects are diminished at certain points in their response curve especially at $120 \mathrm{~min}$. Such a fact may suggest a future protocol to evaluate the effect of incretin therapy on the progression time to frank diabetes in IGT subjects, giving a new hope against that disease.

\section{References}

Brubaker, P. L., \& Drucker, D. J. (2004). Minireview: Glucagon-like peptides regulate cell proliferation and apoptosis in the pancreas, gut, and central nervous system. Endocrinology, 145(6), 2653-2659. http://dx.doi.org/10.1210/en.2004-0015

D'Alessio, D. A., \& Vahl, T. P. (2004). Glucagon-like peptide 1: evolution of an incretin into a treatment for $\begin{array}{llllll}\text { diabetes. } \quad A m . \quad J . & \text { Physiol Endocrinol Metab., 286(6), 882-890. }\end{array}$ http://dx.doi.org/10.1152/ajpendo.00014.2004

Drucker, D. J., \& Nauck, M. A. (2006). The incretin system: glucagon-like peptide-1 receptor agonists and dipeptidyl peptidase-4 inhibitors in type 2 diabetes. Lancet, 368(9548), 1696-1705. http://dx.doi.org/10.1016/S0140-6736(06)69705-5

Dube, P. E., \& Brubaker, P. L. (2004). Nutrient, neural and endocrine control of glucagon-like peptide secretion. Horm. Metab. Res., 36(11-12), 755-760. http://dx.doi.org/10.1055/s-2004-826159

Farilla, L., Bulotta, A., Hirshberg, B., Li Calzi, S., Khoury, N., Noushmehr, H., ... Perfetti, R. (2003). Glucagon-like peptide 1 inhibits cell apoptosis and improves glucose responsiveness of freshly isolated human islets. Endocrinology, 144(12), 5149-5158. http://dx.doi.org/10.1210/en.2003-0323

Gautier, J. F., Fetita, S., Sobngwi, E., \& Salaun-Martin, C. (2005). Biological actions of the incretins GIP and 
GLP-1 and therapeutic perspectives in patients with type 2 diabetes. Diabetes Metab, $31(3 \mathrm{Pt} 1)$, 233-242. http://dx.doi.org/10.1016/S1262-3636(07)70190-8

Gentilcore, D., Chaikomin, R., Jones, K. L., Russo, A., Feinle-Bisset, C., Wishart, J. M., ... Horowitz, M. (2006) Effects of fat on gastric emptying of and the glycemic, insulin, and incretin responses to a carbohydrate meal in type 2 diabetes. J. Clin. Endocrinol Metab., 91(6), 2062-2067. http://dx.doi.org/10.1210/jc.2005-2644

Holst, J. J., \& Gromada, J. (2004). Role of incretin hormones in the regulation of insulin secretion in diabetic and nondiabetic humans. Am. J. Physiol. Endocrinol. Metab., 287(2), 199-206. http://dx.doi.org/10.1152/ajpendo.00545.2003

IDF. (2012). IDF Fact Sheet MENA 2012. Retrieved Last Accesed 25-1-2013, from http://www.idf.org/sites/default/files/IDF_MENA_5E_Update_FactSheet.pdf

Kjems, L. L., Holst, J. J., Volund, A., \& Madsbad, S. (2003). The influence of GLP-1 on glucose-stimulated insulin secretion: effects on beta-cell sensitivity in type 2 and nondiabetic subjects. Diabetes, 52(2), 380-386. http://dx.doi.org/10.2337/diabetes.52.2.380

Knop, F. K., Vilsboll, T., Madsbad, S., Holst, J. J., \& Krarup, T. (2007). Inappropriate suppression of glucagon during OGTT but not during isoglycaemic i.v. glucose infusion contributes to the reduced incretin effect in type 2 diabetes mellitus. Diabetologia, 50(4), 797-805. http://dx.doi.org/10.1152/ajpendo.00289.2007

Meier, J. J., Holst, J. J., Schmidt, W. E., \& Nauck, M. A. (2007). Reduction of hepatic insulin clearance after oral glucose ingestion is not mediated by glucagon-like peptide 1 or gastric inhibitory polypeptide in humans. Am. J. Physiol. Endocrinol. Metab., 293(3), 849-856. http://dx.doi.org/10.1152/ajpendo.00289.2007

Ryskjaer, J., Deacon, C. F., Carr, R. D., Krarup, T., Madsbad, S., Holst, J., \& Vilsboll, T. (2006). Plasma dipeptidyl peptidase-IV activity in patients with type-2 diabetes mellitus correlates positively with HbAlc levels, but is not acutely affected by food intake. Eur. J. Endocrinol., 155(3), 485-493. http://dx.doi.org/10.1530/eje.1.02221

Toft-Nielsen, M. B., Damholt, M. B., Madsbad, S., Hilsted, L. M., Hughes, T. E., Michelsen, B. K., \& Holst, J. J. (2001). Determinants of the impaired secretion of glucagon-like peptide-1 in type 2 diabetic patients. $J$. Clin. Endocrinol. Metab., 86(8), 3717-3723. http://dx.doi.org/10.1210/jc.86.8.3717

Vilsboll, T., \& Holst, J. J. (2004). Incretins, insulin secretion and Type 2 diabetes mellitus. Diabetologia, 47(3), 357-366. http://dx.doi.org/10.1007/s00125-004-1342-6

Vilsboll, T., Krarup, T., Deacon, C. F., Madsbad, S., \& Holst, J. J. (2001). Reduced postprandial concentrations of intact biologically active glucagon-like peptide 1 in type 2 diabetic patients. Diabetes, 50(3), 609-613 http://dx.doi.org/10.2337/diabetes.50.3.609

Vilsboll, T., Krarup, T., Madsbad, S., \& Holst, J. J. (2002). Defective amplification of the late phase insulin response to glucose by GIP in obese Type II diabetic patients. Diabetologia, 45(8), 1111-1119. http://dx.doi.org/10.1007/s00125-002-0878-6

Vozzo, R., Baker, B., Wittert, G. A., Wishart, J. M., Morris, H., Horowitz, M., \& Chapman, I. (2002). Glycemic, hormone, and appetite responses to monosaccharide ingestion in patients with type 2 diabetes. Metabolism, 51(8), 949-957. http://dx.doi.org/10.1053/meta.2002.34012

WHO, I. (2006). Definition and diagnosis of diabetes mellitus and intermediate hyperglycemia: Report of a WHO/IDF consultation. Retrived January 25, 2013, from http://www.who.int/entity/diabetes/publications/diagnosis_diabetes2006/en/index.html

Zander, M., Madsbad, S., Madsen, J. L., \& Holst, J. J. (2002). Effect of 6-week course of glucagon-like peptide 1 on glycaemic control, insulin sensitivity, and beta-cell function in type 2 diabetes: a parallel-group study. Lancet, 359(9309), 824-830. http://dx.doi.org/10.1016/S0140-6736(02)07952-7

\section{Copyrights}

Copyright for this article is retained by the author(s), with first publication rights granted to the journal.

This is an open-access article distributed under the terms and conditions of the Creative Commons Attribution license (http://creativecommons.org/licenses/by/3.0/). 